\title{
Social- and healthcare managers' work wellbeing - literature review and key informant interviews
}

Niina Herttuala Faculty of Social Sciences, Department of Health Sciences, Tampere University, Tampere, Finland and Etelä-Pohjanmaan Sairaanhoitopiiri, Seinäjoki, Finland,

and

Lauri Kokkinen, Faculty of Social Sciences, Department of Health Sciences, Tampere University, Tampere, Finland

and

Anne Konu Faculty of Social Sciences, Department of Health Sciences, Tampere University, Tampere, Finland

\begin{abstract}
Purpose

The purpose of this study was to describe factors that support and prevent managers' work wellbeing by reviewing international studies and interviewing Finnish social- and healthcare managers.

Design/methodology/approach

Twenty-two studies were identified in the systematic literature search. Seven social care and healthcare managers were recruited to participate in thematic interviews. Data were analyzed by using content analysis.
\end{abstract}

\section{Findings}

Supportive and preventive factors for managers' work wellbeing were identified in the literature review, including managerial position, decision latitude, job control, social support and ethical culture at the workplace. The interviews further suggested that the supportive and preventive factors affecting social and healthcare managers' work wellbeing could be divided into five broad categories: 1 . Individual factors, 2. Social factors, 3. Professional support from one's own manager, 4. Work-related factors, and 5. Organizational factors.

\section{Originality/value}

We conducted a systematic literature search together with expert interviews to find the factors most crucial to managers' work wellbeing. These findings can assist social and healthcare organizations and policymakers to pay attention to these factors as well as in policies guiding them.

\section{Introduction}

Improving and maintaining employees' wellbeing is essential because it is important to have healthy people at work and in society in general, and because a healthy workforce is associated with good organizational performance (Day and Nielsen, 2017). The change in the nature and context of work supports a focus on work wellbeing (Guest, 2017). Organizations today are more aware of the happy worker - productive worker thesis, as stated by Nielsen et al. (2017). Furthermore, the potential change in the context of work includes international scientific and political debates about the extension of occupational careers (Mäkikangas et al., 2016). For example, the Ministry of Social Affairs and Health in Finland (2011) has set a goal to increase the duration of working life, which demands a focus on work wellbeing by improving employees' ability, will, and possibilities to work. 
In addition, it is ethically important to focus on employees' wellbeing because work and working conditions can erode work wellbeing, with consequences for employees and, potentially, for organizations. (Guest, 2017).

Work wellbeing can be seen as a part of an individual's holistic wellbeing (Utriainen, 2009), which is comprised of their psychological, social, and physical resources for meeting such challenges. When an individual has more challenges than resources, wellbeing declines and vice versa (Dodge et al., 2012). Physical, mental, and social wellbeing is part of health as defined by the World Health Organization (WHO) (2014). Laine and Rinne (2015) described work wellbeing as "subjectively interpreted holistic mood or affect." Work wellbeing can be defined as including three different components: affecting factors, subjective work wellbeing, and outcome variables (Laine and Rinne, 2015). Participation, autonomy at work, and work control significantly affect work wellbeing (Laine, 2013). One widely used model was proposed by Peter Warr (e.g., Warr, 1992; Guest, 2017). He introduced the employee cognitive affective wellbeing model, which had three axes: displeasedpleased, anxiety-comfort, and depression-enthusiasm.

A single definition of work wellbeing is not commonly accepted (Laine and Rinne, 2015; Utriainen et al., 2015.), and the concept has different meanings depending on research purposes, context, focus, and discipline (Hyvärinen et al., 2017). In the past, research focused on the negative viewpoint of working life (Utriainen et al., 2015; Feldt et al., 2005) and a paradigm based on ill-being conceptualization and stress theories (Laine and Rinne, 2015). As a concept, work wellbeing is nowadays seen through a positive aspect and not only through the consequences of negative manifestations. (Laine et al., 2016) It is important to not only minimize the negative aspects, but also increase positive aspects of health (Day and Nielsen, 2017). The paradigm of work wellbeing has evolved into theories on wellbeing (Laine and Rinne, 2015), and to discussions about how to increase positive workplace factors (e.g., Day and Nielsen, 2017).

Managers hold key positions in the organizational hierarchy (Salmela-Aro et al., 2011; Feldt et al., 2009). They have large amounts of responsibility, have to make unpopular decisions, and must be the center of attention (Skakon et al., 2011). Their role is also to set the direction for their subordinates and communicate in the organization (Salmela-Aro et al., 2011). Managers' own wellbeing has been studied notably less than that of subordinates (Salmela-Aro et al., 2011). As stated by HäggmanLaitila and Romppanen (2018) in their review of nurse leaders' work wellbeing, there is a lack of evidence-based recommendations for effective interventions that inform practice, future studies, and education. The value of the present study arises from investigating the components of managers' work wellbeing that have previously drawn less research attention. The literature uses different terms such as occupational wellbeing, job-related wellbeing, and wellbeing at work. In this study, the concept work wellbeing is used because of its clarity and shortness. Our strategic choice was to use the concept of work wellbeing and not related concepts such as job satisfaction. By focusing on work wellbeing, we gained an understanding on studies using this novel concept. This enabled us to have a clear focus in our review.

\section{Purpose and research questions}

The purpose of this study is to clarify factors that support and prevent managers' work wellbeing by reviewing international research literature and interviewing Finnish social and healthcare managers.

\section{Data collection and analysis}

Literature review: Twenty-two $(n=22)$ research papers were included in the study. We conducted the original data search in November 2016 and completed it in July 2018. Selected databases were international (PsycINFO, Cinahl, EbscoHost Academic Search Premier, Sage, PubMed) and Finnish 
(Arto). Manual search comprises two articles to complete the data search. Table 1 shows the literature search strategy, inclusion criteria and screening.

Table 1. Literature search strategy, inclusion criteria and screening

Table 1. HERE

Interviews: We collected the empirical data from November 2017 to March 2018. Seven managers participated in thematic interviews. Two themes used were supportive and preventive factors for social and healthcare managers' wellbeing at work. In this study, the term "supportive factor" describes factors that improve work wellbeing, and the term "preventive factor" describes factors that deteriorate work wellbeing. We analyzed the data by using conventional content analysis, as described by Hsiu-Fang and Shannon (2005). During the analysis, we read the text data to acquire understanding of the content. The texts were read again to gain a sense of the whole data related to the aim of the study and the data were divided into meaning units (single words, phrases or sentences), which were abstracted and labelled with codes. We categorized meaning units into subcategories, which were then labelled and combined into categories and assigned to themes. Table 2 shows examples of the content analysis categorization.

Table 2. Examples of content analysis procedure

Table 2. HERE

\section{Results}

\section{Literature review}

The literature review revealed factors that support and prevent managers' work wellbeing. Results are shown in Table 3.

Table 3. Managers' work well-being supportive and preventive factors

Table 3. HERE

Twenty-two research articles published between 1982-2018 were included in the literature review (Table 3). The articles were reviewed to determine supportive and/or preventive factors for managers' work wellbeing. As shown in Table 2, the majority had a quantitative approach $(n=20)$. Except for one study from 1982, all the studies were conducted in the 2000s, and half were from Finland $(\mathrm{n}=11)$. Managers were from different disciplines: technical field $(\mathrm{n}=5)$, industry and private sector $(\mathrm{n}=1)$, nursing managers $(n=2)$, school principals $n=(1)$, police managers $(n=1)$, university managers $(n=1)$, or not specified $(\mathrm{n}=11)$.

Table 3 also shows the supportive and preventive factors for managers' work wellbeing identified in the literature review. For example, position in management affected managers' work wellbeing (refs. $4,12,21$ ), as well as higher level of influence (ref. 19), decision latitude (ref. 17) and job control (refs. 1, 20). Social support emerged as a factor that affected positively managers' work wellbeing 
(e.g. refs. 1, 14, 17), as well as ethical culture equating with own ethical perceptions (ref. 5). Ethically challenging situations (ref. 6) and increased emotional demands (ref. 15) were reported as preventive factors for managers' work wellbeing as well as overcommitment (refs. 3, 9) and addiction to work (ref. 2). Effort-reward balance and personal work goals were investigated in few studies (refs. 3, 8, 9, 10 ), and it was shown that, for example, effort-reward imbalance was a preventive factor for work wellbeing.

\section{Interviews}

Figure 1 shows the five categories of social and healthcare managers' work wellbeing that include supportive and preventive factors. The analysis of the interview data identified five categories of factors that support or prevent social and healthcare managers' work wellbeing. Factors were categorized into 1. Individual factors, 2. Social factors at the workplace, 3. Professional support from one's own manager, 4. Organizational factors and 5. Work-related factors. All categories included sub-categories.

\section{Figure 1. HERE}

Fig. 1. Social and healthcare managers' work wellbeing supportive and preventive factors

\section{Individual factors}

Supportive individual factors and abilities were described as mercifulness to oneself, assertiveness, resilience, humor and good self-esteem. Individual factors and abilities also included ability to time manage, delegate and ask for help, finding one's own role as a manager, debating with oneself and knowhow on human resource management. Debating with oneself was seen as not taking work personally, not to let get work too close to oneself, taking work as work and debating in one's own mind. A supportive personal life was seen as an appropriate relation between work and free time and a good life situation in one's personal life. In addition to appropriate relations between work and free time, supportive factors included clearly delimiting work and not answering email and work phones during free time. A good life situation was seen as having a supportive family and life situation. Personal life was described as counterbalancing work, getting thoughts away from work and putting work in perspective:

"There's so much, much more important things in my life than this and in difficult situations it helps me to... somehow to put things [...] in right perspectives, this really is only work..."

A health-promoting way of living was described as recovery and rest, exercise and hobbies. Recovery and rest were seen as having holidays and sleep. Exercise and hobbies were described as getting thoughts off work:

"Your hobbies need to be like your brains have no time to think about your work, you need to focus, whatever it is, you need to be fully concentrated to that, that's really essential" 
Exercise was also seen as getting rid of one's negative feelings:

".. going jogging or [to the] gym, where you can get rid of that adrenalin, exceedingly good were kettlebell classes (laughs), it was very rewarding when you could throw the kettlebell to the ground (laughs), that relieved that aggression notably"

Individual factors and abilities that prevent work wellbeing were described as problems in limiting work, missing know-how, challenges in time management and high demands on oneself.

" if you lash yourself too much, it is going to be hard..."

A challenging life situation in one's personal life was described as preventing work wellbeing. Further individual factors were stress and giving up one's own work wellbeing for subordinates by supporting them, as mentioned by one participant.

\section{Social factors}

Social support was described as support from colleagues, subordinates and political decision makers. Positive feedback was described as praise and giving and having positive feedback. Subordinates' good work wellbeing was mentioned to be important to one's own work wellbeing. A good workplace community was seen as a good atmosphere at the workplace and having one's own 'gang' at the workplace. Staying factual was seen as keeping conversation to the facts although you may not agree with the opposite side:

"you can handle political debate, when it keeps to the facts"

Social factors preventing work wellbeing were described as missing shared goals, missing social support, conflicts, issues get personal and combativeness. Missing social support was seen as working alone. Combativeness was seen as back stabbing, missing sincerity and a focus on one's own career in relation to social and healthcare reform going on in Finland, as was mentioned:

"there is a fight going on about the jobs, even though there is yet nothing to apply for..."

\section{Professional support from one's own manager}

Professional support from one's own manager was seen as a supportive factor.

"meaning of my own manager clearly comes up... even the quiet manager, when you know, that she is there for you to support you, it really means a lot ..."

Missing professional support from one's own manager was seen as a preventive factor:

" that you always have the fear, that is he there for you or not..."

\section{Organizational factors}


Positively experienced values were described as appreciation, experience of fairness and equality. Collaboration was viewed as collaboration within the organization and with political decisionmakers. The possibility to develop knowhow was described as one's own readiness and possibility to develop it and a positive attitude in the organization to developing it:

"Do you have possibilities to develop your know-how, can you maintain your know-how, and are you encouraged to develop yourself?"

Functional guidance in organizations was described as good structures to respond to challenges arising:

"I have tools to respond [to] those challenges arising from personnel and operation...I mean... I have good structures to, for example, intervene in long or sudden absences"

Contradictory or missing guidance and information was described as missing strategies and guidance from administration, or contradictory guidance or information, or guidance that has exceptions:

" it is difficult to implement contradictory guidance"

Negatively experienced values were seen as experienced unfairness, lack of confidence in the organization or subordinates and non-transparent policies in organization. Uncertainty of future was described as uncertain future in relation to social and healthcare reforms and uncertainty about one's own future;

"uncertainty is the biggest disturbing thing, uncertainty of legislation, of course, but uncertainty of continuity of my own work"

Short-sighted planning was described as planning in electoral terms:

"we live in four-year cycles"

Economic fluctuation was another preventive factor for work wellbeing;

“it worries me, that there's no money to work (produce services)... in my position it is... it causes me bad feelings in work".

\section{Work-related factors}

A controllable workload was perceived as a manageable number of tasks and a feeling of control:

"that you have a workload you can manage, it is really essential"

Autonomy at work was seen as freedom to organize one's working day and tasks independently and freedom to complete single tasks in leisure time if necessary. Clear tasks were seen as a clear order of tasks and clearly defined tasks. Functional work arrangements were identified as the possibility for flexible working times, remote work and mobile systems for recording and controlling working hours. Successfully cleared tasks were described as succeeding in tasks, progressing tasks and completing them. 


\section{Discussion}

This study describes factors that support and factors that prevent managers' work wellbeing. These factors were identified in a literature review and analysis of interviews of Finnish social and healthcare managers. The literature review identified several specific factors that affect managers' work wellbeing, such as managerial position, decision latitude, job control, social support and ethical culture at the workplace. Analysis of the interviews suggested five broad categories that affect managers' work wellbeing: individual factors, social factors, professional support from one's own manager, organizational factors, and work-related factors, all of which include factors that support and factors that prevent managers' work wellbeing.

Laine and Rinne (2015) suggest that the nature of work wellbeing is dynamic and that it is possible to identify factors that support or prevent it. In this study we used expert interviews to understand the dynamics of several supportive and preventive factors for work wellbeing. For example, we found that having professional support from one's own manager supported work wellbeing, whereas lack of it was detrimental to work wellbeing. Furthermore, this study partly supports Laine's (2013) conceptual model of work wellbeing, where participation, autonomy at work and work control affected work wellbeing. In our study, work autonomy and work control affected managers' work wellbeing as predicted by Laine's (2013) model, whereas participation did not occur to affect managers' work wellbeing.

The results of this study highlight components of the IGLO-model (the Individual, the Group, The Leader, the Organizational level) (Day and Nielsen, 2017). The IGLO-model suggests that the antecedents of employee health and wellbeing can be classified according to these four levels. (Nielsen et al., 2017). Day and Nielsen (2017) suggest that these levels identify psychologically healthy workplaces, where all IGLO levels are promoted to ensure employee wellbeing and performance (Nielsen et al., 2017). Furthermore, the extended IGLOO-framework includes, "the Overarching, i.e., the wider social and cultural context and the suggested non-work resources at each level" (Nielsen et al., 2018). In the results of this study, social and healthcare managers' work wellbeing is affected by several factors included not only factors present at the workplace, but also in personal life.

According to previous studies, managers' work wellbeing is good in different disciplines (e.g., Nyberg et al., 2015; Mäkikangas et al., 2011; Feldt et al., 2005), and better than that of workers (Rollero et al., 2016), and managers report less stress than the employees (Skakon et al., 2011). Managerial positions are influential and managers have less short-term sickness absence than workers. On the other hand, managers' work is often demanding and they suffer problems in worklife balance. (Nyberg et al., 2015) Maxwell and Riley (2017) even found that school principals experienced more burnout, less job satisfaction, and notably less wellbeing than the general population. Managers carry financial responsibility in their organizations, and our study showed that economic fluctuations could affect managers' work wellbeing. Furthermore, managerial tasks include cascading organizational policies and decisions downward through the organization (Noblet et al., 2001), and, because of that, unclear guidance and information can affect managers' work wellbeing negatively. Our study also showed that subordinates' good work wellbeing is important for managers' work wellbeing, as is managers' knowhow on human resources. According to our results, critical attitudes from political decision makers can have a negative effect on managers' work wellbeing and the same applies to short-sighted planning (e.g. in electoral terms). In turn, good collaboration with political decision makers affected managers' work wellbeing positively.

Individual factors, such as ability to manage time, delegate, and ask for help, were seen as important for maintaining work wellbeing. In turn, problems in limiting work, missing know-how, challenges in time management, and high demands on oneself were considered to prevent work wellbeing. 
According to this study, know-how on human resources supports work wellbeing. Earlier studies have shown that when an employee is satisfied with self-competence, that satisfaction supports work wellbeing (Hyvärinen et al., 2017); we found that the same mechanism affects managers' work wellbeing. Skakon et al. (2011) states that, partly because of possibilities for development, managers experienced significantly lower emotional stress than their employees.

According to this study, personal life counterbalances work, gets thoughts off work and puts work in the right perspective. The right relationship between work and free time (i.e. delimiting emails and turning the work phone off during free time) and a good life situation in one's personal life were mentioned to be important. These results support a previous study on flight attendants that showed that spending time on work-related activities during off-job time decreased wellbeing and experiencing off-job time activities improved wellbeing (Sonnentag and Natter, 2004). This study suggests that the right relationship between work and free time, hobbies and exercising are supportive factors for managers' work wellbeing. In addition, physical activities have been proved to increase work wellbeing (Sonnentag and Natter, 2004), as was shown in this study also. On the other hand, challenging situations in personal lives and stress prevent work wellbeing.

In this study, social factors at the workplace supported managers' work wellbeing. One of these factors was a good workplace community. Lampinen, Viitanen and Konu (2013) stated in their literature review of sense on belonging in the workplace, that human relations are a key factor in achieving a sense of belonging, which supports health, wellbeing, learning and productivity (Lampinen et al., 2013). This study suggests that social support (e.g. from colleagues) supports wellbeing. However, Adriaenssens, Hamelink and Van Bogaert (2017) found that social support from colleagues was not a predictor of occupational wellbeing in first-line nurse managers. Our results showed that some social factors prevent work wellbeing (e.g. conflicts). Managers face ethically challenging situations with conflicts at the workplace, which burdens managers (Huhtala et al., 2011b; Huhtala et al., 2010) and threatens their work wellbeing (Huhtala et al., 2011b), as shown in this study also.

Support from one's own manager seems to be a key factor in maintaining work wellbeing, while missing manager support was seen as a preventive factor. In their systematic review, Skakon et al. (2010) found support for the idea that positive leader behaviors (e.g., support, feedback, trust) are associated with employees' affective wellbeing, less stress, and coping with stress. There is also evidence of an association between support for managers by their supervisors and job satisfaction (Lee and Cummings, 2008). Furthermore, social support from management was predictive of turnover intention (Adriaenssens et al., 2017) and decreased stress for male leaders (Luszczynska and Cieslak, 2005). However, one previous study suggested that for one-quarter (22\%) of first-line nurse managers, managerial guidance was insufficient (Johansson et al., 2013).

Regarding work-related factors, our finding that clear tasks support work wellbeing is in line with previous findings that first-line nurse managers' complex and unclear role might result in occupational stress and turnover (Adriaenssens et al., 2017). According to previous studies (e.g. Bakker et al., 2003) job demands (e.g. work overload) are one of the most important predictors of employees' levels of exhaustion and repetitive strain injury (Bakker et al., 2003). In this study, tight deadlines, hurry and overwhelming responsibilities were found to decrease managers' work wellbeing. In turn, our study showed that a controllable workload, achievable deadlines and work autonomy support managers' work wellbeing. This is in line with a previous study (Feldt et al., 2009).

Organizational factors affected social and healthcare managers' work wellbeing. For example, positively experienced values (e.g. appreciation), trust and collaboration were considered important for work wellbeing. As shown before, trust, respect and appreciation were mentioned to be important to a sense of belonging among social and healthcare managers (Lampinen et al., 2018). Collaboration within the organization and with political decision makers was seen as a supportive factor for work wellbeing. Our study showed that a critical attitude from political decision makers prevents work 
wellbeing, as political decision makers have an important role in guiding social care and healthcare. At the time of the interviews, preparations for major social and healthcare reform were on their way in Finland, and future uncertainty was one concern of the managers interviewed. Mäkikangas et al., (2011) found that job insecurity decreased occupational wellbeing, and our study confirms their finding. Furthermore, organizational changes may cause changes to the manager community (Lampinen et al., 2018) that may affect managers' work wellbeing negatively (Kokkinen and Konu 2012). According to this study, short-sighted planning prevents social and healthcare managers' work wellbeing. This might arise because decisions are made in electoral terms, and following elections new political decision makers may change the course of reforms.

\section{Limitations}

The major limitation of this study is that we had no definite way of assessing how many managers to interview. Our decision to do seven interviews was based on previous study, were basic elements for metathemes were found to be present as early as six interviews. (Guest et al., 2006). We first interviewed five managers in a group, and then two managers separately. These seven interviews produced a rich understanding of the studied issue. Beyond this methodological limitation, the context of our study should also be noted. The majority of the previous work wellbeing studies have been carried out in Finland. The concept of work wellbeing was familiar to our interviewees, but this might not be the case in other countries. Furthermore, we only studied the factors affecting social and healthcare managers' work wellbeing. The social and healthcare sector is characterized by the socalled political-bureaucratic-professional tradition (Viitanen et al., 2007) that separates it clearly from other sectors and may well affect the work wellbeing of social and healthcare managers. However, we systematically reviewed all the international literature on managers' work wellbeing to find factors most crucial to managers' work wellbeing and then recruited Finnish social and healthcare managers to find the factors specifically affecting their work wellbeing.

\section{Ethical consideration}

This study was conducted according to the responsible conduct of research, as stated by the Finnish Advisory Board of Research Integrity (2012). Participation in interviews was voluntary and participants provided their informed consent. Collected data was secured, and participants are not identified in this report.

\section{Implications for practice}

This paper illustrates the factors that support and prevent social and healthcare managers' work wellbeing. These results can be used when developing social and healthcare managers' work wellbeing policies in organizations. Factors that affect managers' work wellbeing are mostly similar to those that affect employees' work wellbeing. However, there are some characteristics in managers' work wellbeing. Because of managers' demanding work, attention should be paid to managers' individual factors, such as recovery from work. Social factors in the workplace, such as social support, a good workplace community and positive feedback, are factors that should be highlighted. 
Professional support from one's own manager seems to be a key factor maintaining managers' work wellbeing and it should be noted. Organizations should recognize work-related factors, such as workload and achievable deadlines. An open conversation is needed about organizational factors, such as values espoused in organizations. Organization should set goals to ensure managers' work wellbeing (as well as their subordinates) and clearly set these goals in policies and practice.

\section{Conclusions}

This paper has illustrated supportive and preventive factors that affect social and healthcare managers' work wellbeing. Based on previous studies, several factors, such as managerial position, decision latitude, job control, social support and ethical culture at the workplace affect managers' work wellbeing. Factors that affect social and healthcare managers' work wellbeing are diverse. Individual and social factors, professional support from one's own manager, work-related factors and organizational factors all affect their work wellbeing. The lack of earlier studies shows the need for these studies. We need up-to-date research of social and healthcare managers' work wellbeing to point out possible needs for development. For example, a survey which measures work wellbeing particular to social and healthcare managers would bring us valuable information, and address the most important factors.

\section{References}

Adriaenssens, J., Hamelink, A. and Bogaert, P. V. (2017). Predictors of occupational stress and wellbeing in first-line nurse managers: A cross-sectional survey study. International Journal of Nursing Studies, Vol. 73, 85-92.

Bakker, A. B., Demerouti, E. and Schaufeli, W. B. (2003). Dual processes at work in a call centre: An application of the job demands-resources model. European Journal of Work and Organizational Psychology, Vol. 12 No. 4, pp 393-417.

Burke, R. J. and Fiksenbaum, L. (2009). Work motivations, satisfactions, and health among managers: Passion versus addiction. Cross-Cultural Research: The Journal of Comparative Social Science, Vol. 43 No. 4, pp. 349-365.

Day, A. and Nielsen, K. (2017). What does our organization do to help our well-being? Creating healthy workplaces and workers. In Chmiel, N., Fraccoli, F and Sverke, M. (Ed.), An introduction to work and organizational psychology: An international perspective, Sussex: Wiley Blackwell, pp. 295-314.

Dodge, R., Daly, A., Huyton, J. and Sanders, L. (2012). The challenge of defining wellbeing. International Journal of Wellbeing, Vol. 2 No. 3, pp. 222-235. Available at: https://www.internationaljournalofwellbeing.org/index.php/ijow/article/view/89 (Accessed 06 February 2019).

Feldt, T., Huhtala, M., Kinnunen, U., Hyvönen, K., Mäkikangas, A. and Sonnentag, S. (2013). Longterm patterns of effort-reward imbalance and over-commitment: Investigating occupational wellbeing and recovery experiences as outcomes. Work \& Stress, Vol. 27 No. 1, pp. 64-87.

Feldt, T., Hyvönen, K., Mäkikangas, A., Kinnunen, U. and Kokko, K. (2009). Development trajectories of Finnish managers' work ability over a 10-year follow-up period. Scandinavian Journal of Work, Environment \& Health, Vol. 35 No. 1, pp. 37-47. 
Feldt, T., Kinnunen, U. and Mäkikangas, A. (2005). Affektiivisen työhyvinvoinnin rakenne ja pysyvyys kolmen vuoden seuruututkimuksessa. [The structure and stability of job-related affective well-being over a three-year follow-up study.] Psykologia, Vol. 40 No. 5-6, pp. 541-551.

Guest, D. E. (2017). Human resource management and employee well-being: Towards a new analytic framework. Human Resource Management Journal, Vol. 27 No. 1, pp. 22-38.

Guest, G., Bunce, A. and Johnson, L. (2006). How Many Interviews Are Enough? An Experiment with Data Saturation and Variability. Field Methods, Vol. 18 No. 1, pp. 59-82.

Häggman-Laitila, A. and Romppanen, J. (2018). Outcomes of interventions for nurse leaders' wellbeing at work: A quantitative systematic review. Journal of Advanced Nursing, Vol. 747 No. 1, pp. 34-44.

Hsiu-Fang H. and Shannon, S. E. (2005). Three approaches to qualitative content analysis. Qualitative Health Research, Vol. 15 No. 9, pp. 1277-1288.

Huhtala, M., Feldt, T., Lämsä, A., Mauno, S. and Kinnunen, U. (2011a). Does the Ethical Culture of Organizations Promote Managers' Occupational Well-Being? Investigating Indirect Links via Ethical Strain. Journal of Business Ethics, Vol. 101 No. 2, pp. 231-247.

Huhtala, M., Lähteenkorva, L. and Feldt, T. (2011b). Johtajien työn eettinen kuormittavuus ja sen yhteydet työhyvinvointiin. Työelämän tutkimus - Arbetslivforskning, Vol. 9 No. 2, pp. 136-152.

Huhtala, M., Puutio, R., Lämsä, A-M., Mauno, S., Kinnunen, U., Hyvönen, T. and Feldt, T. (2010). Eettisesti haastavat tilanteet ja niiden kuormittavuus johtajien työssä: Fokusryhmäkeskusteluiden analyysi. Työelämän tutkimus - Arbetslivforskning, Vol. 8 No. 1, pp. 13-25.

Hyvärinen, K., Saaranen, T. and Tossavainen, K. (2017). Ammatillinen osaaminen työhyvinvoinnin osana -- kyselytutkimus terveysalan opettajille. [Professional Competence as a Part of Occupational Wellbeing -a Survey for healthcare sector teachers.] Hoitotiede, Vol. 29 No. 4, pp. 252-263.

Hyvönen, K., Feldt, T., Kinnunen, U. and Tolvanen, A. (2011). Changes in personal work goals in relation to the psychosocial work environment: A two-year follow-up study. Work \& Stress, Vol. 25 No. 4, pp. 289-308.

Hyvönen, K., Feldt, T., Tolvanen, A. and Kinnunen, U. (2010). The role of goal pursuit in the interaction between psychosocial work environment and occupational well-being. Journal of Vocational Behavior, Vol. 76 No. 3, pp. 406-418.

Hyvönen, K., Rantanen, J., Huhtala, M., Wiese, B. S., Tolvanen, A. and Feldt, T. (2015). Conflicting personal goals: A risk to occupational well-being? Journal of Managerial Psychology, Vol. 30 No. 8, pp. 1034-1048.

Ivancevich, J. M., Matteson, M. T. and Preston, C. (1982). Occupational stress, type A behavior, and physical wellbeing. Academy of Management Journal, Vol. 25 No. 2, pp. 373-391.

Johansson, G. Sandahl, C. and Hasson, D. (2013). Role stress among first-line nurse managers and registered nurses - a comparative study. Journal of Nursing Management, Vol. 21 No. 3, pp. 449-458.

Kirkcaldy, B., Petersen, L., and Hubner, G. (2002). Managing the stress of bringing the economy in the Eastern German states to the level of the Western German states: A comparison of occupational stress, physical and psychological well-being and coping among managers from West and the former East Germany. European Psychologist, Vol. 7 No. 1, pp. 53-62.

Kokkinen, L. and Konu, A. (2012). Work ability of employees in changing social services and health care organizations in Finland. International Journal of Occupational Medicine and Environmental Health, Vol. 25 No. 2, pp. 151-165. 
Laine, P. (2013). Työhyvinvoinnin kehittäminen. Hyvän kehittämisen reunaehtoja tutkimassa.

[Developing wellbeing at work. In search of a good development process.] Doctoral

Dissertations. Turku, Turku University. Available at:

http://www.utupub.fi/handle/10024/93684 (Accessed 07 February 2019).

Laine, P., M. Lindberg, M. and Silvennoinen, H. (2016) Työhyvinvoinnista tarvitaan väestötason seurantatietoa - Työhyvinvoinnin käsite ja mittaamisen problematisointia ja kehittelyä. [A need for population-level studies - The concept of work wellbeing and problematizing measurement and development.] Hallinnon Tutkimus, Vol. 34 No. 4, pp. 287-303.

Laine, P. and Rinne, R. (2015). Developing wellbeing at work: Emerging dilemmas. International Journal of Wellbeing, Vol. 5 No. 2, pp. 91-108.

https://www.internationaljournalofwellbeing.org/index.php/ijow/article/view/359 [Accessed 06.02.2019].

Lampinen, M., Konu, A. I., Kettunen, T., and Suutala, E. A. (2018). Factors that foster or prevent sense of belonging among social and health care managers. Leadership in Health Services, Vol. 31 No. 4, pp. 468-480.

Lampinen, M-S., Viitanen, A. and Konu, A. (2013) Systemaattinen kirjallisuuskatsaus yhteisöllisyydestä työelämässä. [A systematic review of sense of community at work]. Sosiaalilääketieteellinen aikakauslehti, Vol. 50 No. 1, pp. 71-86.

Lee, H. and Cummings, G. G. (2008). Factors influencing job satisfaction of frontline nurse managers: A systematic review. Journal of Nursing Management, Vol. 16 No. 7, pp. 768-783.

Luszczynska, A. and Cieslak, R. (2005). Protective, promotive, and buffering effects of perceived social support in managerial stress: The moderating role of personality. Anxiety, Stress, \& Coping, Vol. 18 No. 3, pp. 227-244.

Mäkikangas, A., Feldt, T., and Kinnunen, U. (2007). Warr's scale of job-related affective well-being: A longitudinal examination of its structure and relationships with work characteristics. Work \& Stress, Vol. 21 No. 3, pp. 197-219.

Mäkikangas, A., Hyvönen, K., Leskinen, E., Kinnunen, U., and Feldt, T. (2011). A person-centred approach to investigate the development trajectories of job-related affective well-being: A 10year follow-up study. Journal of Occupational \& Organizational Psychology, Vol. 84 No. 2, pp. 327-346.

Mäkikangas, A., Kinnunen, U., Feldt, T., and Schaufeli, W. (2016). The longitudinal development of employee well-being: A systematic review. Work \& Stress, Vol. 30 No. 1, pp. 46-70.

Maxwell, A., and Riley, P. (2017). Emotional demands, emotional labour and occupational outcomes in school principals: Modelling the relationships. Educational Management Administration \& Leadership, Vol. 45 No. 3, pp. 484-502.

Mencl, J., Wefald, A. J. and van Ittersum, K. W. (2016). Transformational leader attributes: Interpersonal skills, engagement, and well-being. Leadership \& Organization Development Journal, Vol. 37 No. 5, pp. 635-657.

Ministry of Social Affairs and Health in Finland (2011). Työympäristön ja työhyvinvoinnin linjaukset vuoteen 2020. Helsinki: Ministry of Social Affairs and Health in Finland.

Nielsen, K., Nielsen, M. B., Ogbobonnaya, C., Kansala, M., Saari, E. and Isaksson, K. (2017) Workplace resources to improve both employee well-being and performance: A systematic review and meta-analysis. Work \& Stress, Vol. 31 No. 2, pp. 101-120.

Nielsen, K., Yarker, J., Munir, F. and Bultmann, U. (2018). IGLOO: An integrated framework for sustainable return to work in workers with common mental disorders. Work \& Stress, Vol. 32 No. 4, pp. 400-417. 
Noblet, A., Rodwell, J. and McWilliams, J. (2001). The job strain model is enough for managers. Journal of Managerial Psychology, Vol. 16 No. 7, pp. 635-649.

Nyberg, A., Leineweber, C. and Magnusson Hanson, L. (2015). Gender differences in psychosocial work factors, work-personal life interface, and well-being among Swedish managers and nonmanagers. International Archives of Occupational \& Environmental Health, Vol. 88 No. 8, pp. 1149-1164.

Pagon, M., Spector, P. E., Cooper, C. L. and Lobnikar, B. (2011). Managers in suits and managers in uniforms: Sources and outcomes of occupational stress. International Journal of Police Science \& Management, Vol. 13 No. 3, pp. 211-222.

Rollero, C., Fedi, A. and De Piccoli, N. (2016). Gender or occupational status: What counts more for well-being at work? Social Indicators Research, Vol. 128 No. 2, pp. 467-480.

Salmela-Aro, K., Rantanen, J., Hyvönen, K., Tilleman, K. and Feldt, T. (2011). Bergen burnout inventory: Reliability and validity among Finnish and Estonian managers. International Archives of Occupational \& Environmental Health, Vol. 84 No. 6, pp. 635-645.

Schmitt, A., Zacher, H. and Frese, M. (2012). The buffering effect of selection, optimization, and compensation strategy use on the relationship between problem solving demands and occupational well-being: A daily diary study. Journal of Occupational Health Psychology, Vol. 17 No. 2, pp. 139-149.

Skakon, J., Kristensen, T. S., Christensen, K. B., Lund, T and Labriola, M. (2011) Do managers experience more stress than empoyees? Results from the Intervention Project on Absence and Well-being (IPAW) study among Danish managers and their employees. Work: Journal of Prevention, Assessment \& Rehabilitation, Vol 38 No. 2, pp. 103 -109.

Skakon, J., Nielsen, K., Borg, W. and Guzman, J. (2010) Are leaders' well-being, behaviours, and style associated with the affective well-being of their employees? A systematic review of three decades of research. Work \& Stress, Vol 24 No. 2, pp. 107-139.

Sonnentag, S. and Natter, E. (2004). Flight attendants' daily recovery from work: Is there no place like home? International Journal of Stress Management, Vol. 11 No. 4, pp. 366-391.

The Finnish Advisory Board on Research Integrity (2012). Responsible conduct of research and procedures for handling allegations of misconduct in Finland. Available at: http://www.tenk.fi/sites/tenk.fi/files/HTK_ohje_2012.pdf (Accessed 07 February 2019).

Utriainen, K. (2009). Arvostava vastavuoroisuus ikääntyvien sairaanhoitajien työhyvinvoinnin ytimenä hoitotyössä. [Appreciative reciprocity as the core of well-being at work of ageing nurse.] Doctoral Dissertations. Oulu, Oulu University. Available at: http://jultika.oulu.fi/files/isbn9789514291128.pdf (Accessed 07 February 2019).

Utriainen, K., Ala-Mursula, L. and Kyngäs, H. (2015). Hospital nurses' wellbeing at work: A theoretical model. Journal of Nursing Management, Vol. 23 No. 6, pp. 736-743.

Viitanen, E., Kokkinen, L., Konu, A., Simonen, O., Virtanen, J.V. and Lehto, J. (2007). Johtajana sosiaali- ja terveydenhuollossa. Kunnallisalan kehittämissäätiö, Vammala. Available at https://docplayer.fi/2091174-Johtajana-sosiaali-ja-terveydenhuollossa.html (Accessed 19 February 2019).

Warr P. (1992). Age and occupational well-being. Psychology \& Aging, Vol. 7 No. 1, pp. 37-45.

World Health Organization. (2014). "Basic Documents" available at http://apps.who.int/gb/bd/PDF/bd48/basic-documents-48th-edition-en.pdf\#page=1 (Accessed 25 January 2019). 
Supportive factors

- Supportive individual factors and abilities

- Supportive personal life

- Health promoting way of living

- Having responsibility

\section{Preventive factors}

- Preventive individual factors and abilities

- Challenging life situation in personal life

- Stress

- Giving up one's own work wellbeing

Supportive factors

- Controllable workload

- Autonomy at work

- Clear tasks

- Functional work arrangements

- Successfully cleared tasks

- Achievable deadlines

Preventive factors

- Tight deadlines

- Work doesn't run smoothly

- Hurry

- Overwhelming responsibilities

- Failure in work
1. Individual factors

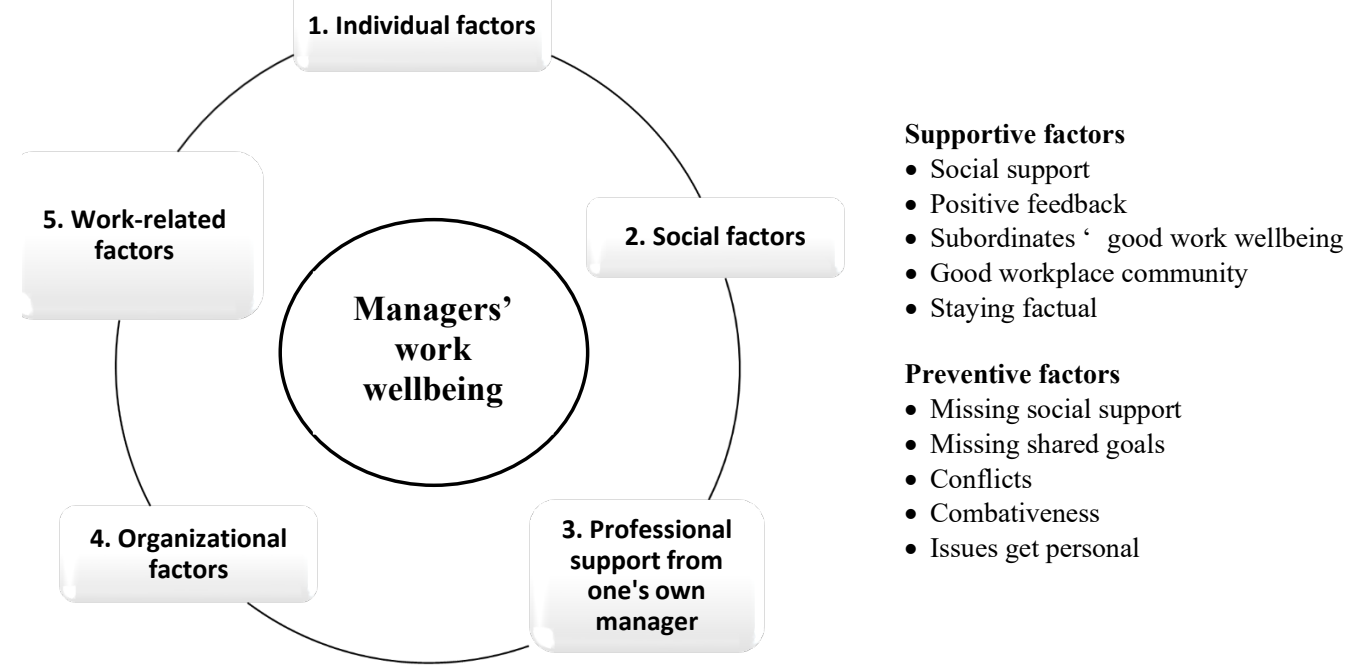

Supportive factors

- Positively experienced values

- Collaboration

- Trust

- Income

- Possibility to develop one's knowhow

- Functional guidance in organization

Preventive factors

- Missing guidance and information

- Bureaucracy

- Unclear responsibilities

- Negatively experienced values

- Future uncertainty

- Short-sighted planning

- Economical fluctuations

- Critical attitude from political decision makers
Supportive factors

- Support from one's own manager

- Time, listening and conversation with one's own manager

- Available manager

- Manager gives support to developing oneself

Preventive factors

- Missing manager support

- Manager doesn't ask how's it going

- Manager doesn't keep promises

- Fear that the manager is not there for you 


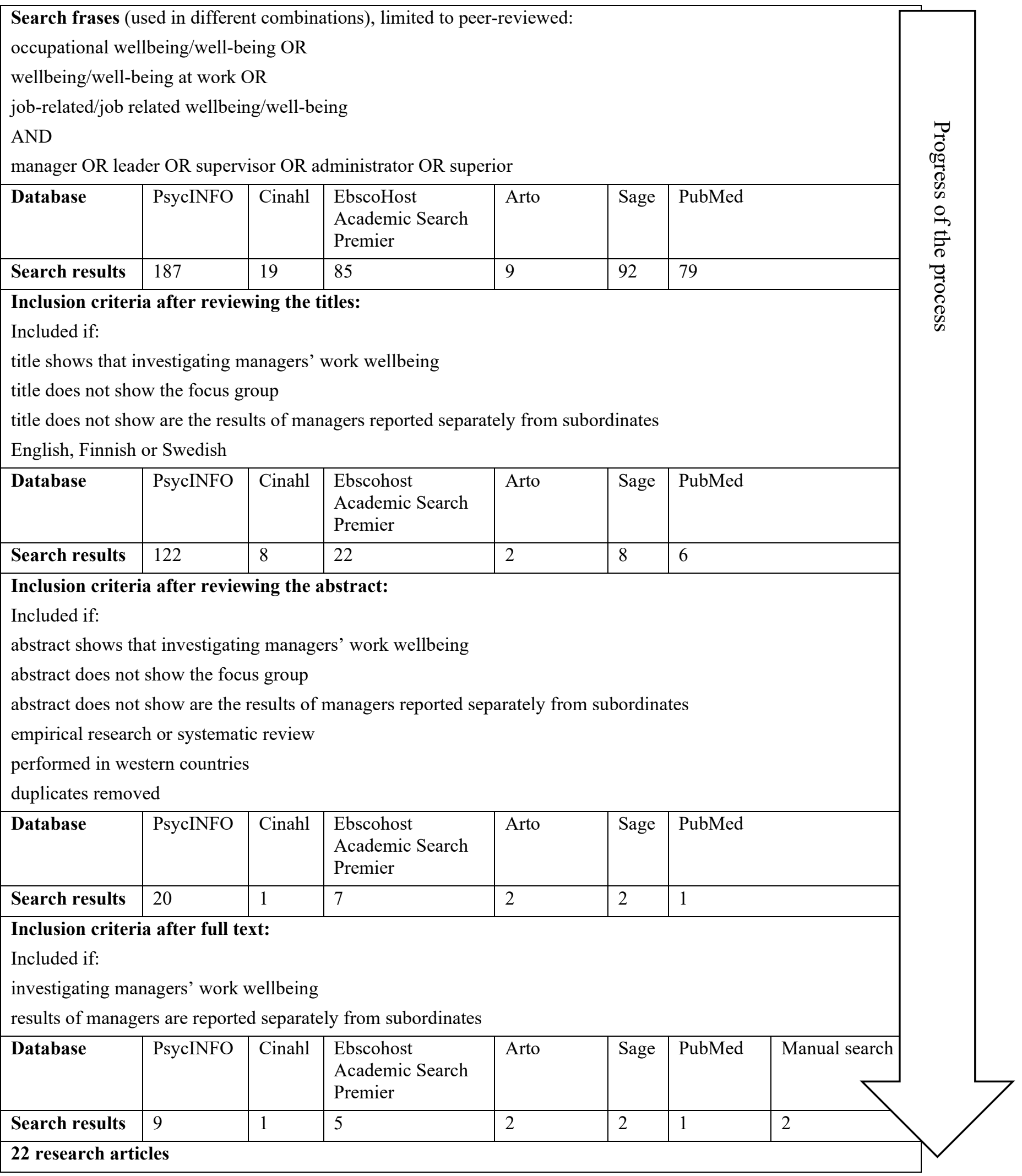




\begin{tabular}{|c|c|c|c|c|}
\hline Meaning unit & Code & Subcategory & Category & Theme \\
\hline $\begin{array}{l}\text { I have support from my } \\
\text { manager... } \\
\text { meaning of my own manager } \\
\text { clearly comes up... even the } \\
\text { quiet manager, when you } \\
\text { know, that she is there for you } \\
\text { to support you, it really means } \\
\text { a lot... } \\
\text { there's a feeling and thought } \\
\text { about it, that I have support }\end{array}$ & $\begin{array}{l}\text { support from own } \\
\text { manager } \\
\text { support from own } \\
\text { manager } \\
\text { feeling that } \\
\text { manager is there } \\
\text { for you } \\
\text { support from own } \\
\text { manager }\end{array}$ & $\begin{array}{l}\text { support from } \\
\text { one's own } \\
\text { manager }\end{array}$ & $\begin{array}{l}\text { Professional support } \\
\text { from one's own } \\
\text { manager }\end{array}$ & $\begin{array}{l}\text { Supportive } \\
\text { factors }\end{array}$ \\
\hline $\begin{array}{l}\text { she (own manager) was in a } \\
\text { way available.. if I had } \\
\text { something, she was there and } \\
\text { I could contact her..." }\end{array}$ & $\begin{array}{l}\text { manager is } \\
\text { available }\end{array}$ & available manager & & \\
\hline $\begin{array}{l}\text {.. you always have the fear, } \\
\text { that is he there for you or } \\
\text { not... } \\
\text {...my manager trusts me so } \\
\text { much he doesn't even bother } \\
\text { to ask how's it going or how } \\
\text { are we doing... I would } \\
\text { experience it positively, if he } \\
\text { asked how are you and is } \\
\text { everything ok... }\end{array}$ & $\begin{array}{l}\text { fear that manager } \\
\text { is not there for } \\
\text { you } \\
\text { manager doesn't } \\
\text { ask how it's going }\end{array}$ & $\begin{array}{l}\text { fear that manager } \\
\text { is not there for } \\
\text { you } \\
\text { manager doesn't } \\
\text { ask how it's going }\end{array}$ & $\begin{array}{l}\text { Professional support } \\
\text { from one's own } \\
\text { manager }\end{array}$ & $\begin{array}{l}\text { Preventive } \\
\text { factors }\end{array}$ \\
\hline
\end{tabular}




\begin{tabular}{|c|c|c|c|c|}
\hline $\begin{array}{l}\text { Ref. } \\
\text { No. }\end{array}$ & & Supportive factors & Preventive factors & $\begin{array}{l}\text { Country, approach, } \\
\text { discipline }\end{array}$ \\
\hline 1. & $\begin{array}{l}\text { Adriaenssens, } \\
\text { Hamelink and Van } \\
\text { Bogaert, } 2017\end{array}$ & $\begin{array}{l}\text { social support from staff members } \\
\text { social support from management } \\
\text { job control } \\
\text { job demands (a positive perception of work/time demands) } \\
\text { collaboration with co-operation partners }\end{array}$ & & $\begin{array}{l}\text { Belgium, quantitative, } \\
\text { nursing }\end{array}$ \\
\hline 2. & $\begin{array}{l}\text { Burke and } \\
\text { Fiksenbaum, } 2009\end{array}$ & passion for work & addiction to work & $\begin{array}{l}\text { Canada, quantitative, } \\
\text { not specified }\end{array}$ \\
\hline 3. & $\begin{array}{l}\text { Feldt, Huhtala, } \\
\text { Kinnunen, Hyvönen, } \\
\text { Mäkikangas and } \\
\text { Sonnentag, } 2013\end{array}$ & & $\begin{array}{l}\text { effort-reward imbalance } \\
\text { overcommitment }\end{array}$ & $\begin{array}{l}\text { Finland, quantitative, } \\
\text { technical field }\end{array}$ \\
\hline 4. & $\begin{array}{l}\text { Feldt, Kinnunen and } \\
\text { Mäkikangas, } 2005\end{array}$ & position in upper management & $\begin{array}{l}\text { position in lower management or } \\
\text { supervision of work }\end{array}$ & $\begin{array}{l}\text { Finland, quantitative, } \\
\text { technical field and } \\
\text { engineering }\end{array}$ \\
\hline 5. & $\begin{array}{l}\text { Huhtala, Feldt, Lämsä, } \\
\text { Mauno and Kinnunen, } \\
2011\end{array}$ & ethical culture in organisation equates with own ethical perceptions & & $\begin{array}{l}\text { Finland, quantitative, } \\
\text { managers in business } \\
\text { administration and } \\
\text { engineering }\end{array}$ \\
\hline 6. & $\begin{array}{l}\text { Huhtala, Lähteenkorva } \\
\text { and Feldt, } 2011\end{array}$ & & $\begin{array}{l}\text { ethically challenging situations } \\
\text { caused stress } \\
\text { women reported more stress than } \\
\text { men } \\
\text { stress decreased work wellbeing }\end{array}$ & $\begin{array}{l}\text { Finland, quantitative, } \\
\text { managers in business } \\
\text { administration and } \\
\text { engineering }\end{array}$ \\
\hline 7. & $\begin{array}{l}\text { Huhtala, Puutio, } \\
\text { Lämsä, Mauno, } \\
\text { Kinnunen, Hyvönen } \\
\text { and Feldt, } 2010\end{array}$ & & ethically challenging situations & $\begin{array}{l}\text { Finland, qualitative, } \\
\text { private and public } \\
\text { sector }\end{array}$ \\
\hline 8. & $\begin{array}{l}\text { Hyvönen, Feldt, } \\
\text { Kinnunen and } \\
\text { Tolvanen, } 2011\end{array}$ & & effort-reward imbalance & $\begin{array}{l}\text { Finland, qualitative and } \\
\text { quantitative, technical } \\
\text { field }\end{array}$ \\
\hline 9. & $\begin{array}{l}\text { Hyvönen, Feldt, } \\
\text { Tolvanen and } \\
\text { Kinnunen, } 2010\end{array}$ & $\begin{array}{l}\text { effort-reward balance } \\
\text { personal work goals are organisational goals (focusing on the success of } \\
\text { the team, department or organisation) }\end{array}$ & $\begin{array}{l}\text { overcommitment } \\
\text { personal work goals are well- } \\
\text { being, job change or no work goal }\end{array}$ & $\begin{array}{l}\text { Finland, quantitative, } \\
\text { technical field }\end{array}$ \\
\hline
\end{tabular}




\begin{tabular}{|c|c|c|c|c|}
\hline 10. & $\begin{array}{l}\text { Hyvönen, Rantanen, } \\
\text { Huhtala, Wiese, } \\
\text { Tolvanen and Feldt, } \\
2015\end{array}$ & personal work goals are progression goals & $\begin{array}{l}\text { personal work goals are well- } \\
\text { being goals, career-ending goals } \\
\text { and job change goals }\end{array}$ & $\begin{array}{l}\text { Finland, quantitative, } \\
\text { field not mentioned }\end{array}$ \\
\hline 11. & $\begin{array}{l}\text { Häggman-Laitila and } \\
\text { Romppanen, } 2018\end{array}$ & $\begin{array}{l}\text { stress management interventions that included mental exercises reduced } \\
\text { the stress experienced by participants }\end{array}$ & & $\begin{array}{l}\text { Finland, systematic } \\
\text { review, nurse leaders }\end{array}$ \\
\hline 12. & $\begin{array}{l}\text { Ivancevich, Matteson } \\
\text { and Preston, } 1982\end{array}$ & position in lower or upper management & position in middle management & $\begin{array}{l}\text { USA, quantitative, } \\
\text { private sector/industry }\end{array}$ \\
\hline 13. & $\begin{array}{l}\text { Kirkcaldy, Petersen } \\
\text { and Hubner, } 2002\end{array}$ & $\begin{array}{l}\text { managers with type B behaviour, stress-coping factors and other } \\
\text { buffering moderator agents, had fewer potential negative effects of stress }\end{array}$ & $\begin{array}{l}\text { managers with type A behaviour, } \\
\text { lower levels of coping skills and } \\
\text { external locus of control reported } \\
\text { inferior psychological health }\end{array}$ & $\begin{array}{l}\text { Germany, quantitative, } \\
\text { private and public } \\
\text { sector }\end{array}$ \\
\hline 14. & $\begin{array}{l}\text { Luszczynska and } \\
\text { Cieslak, } 2005\end{array}$ & $\begin{array}{l}\text { social support from colleagues and family } \\
\text { social support from manager }\end{array}$ & & $\begin{array}{l}\text { Poland, quantitative, } \\
\text { industry }\end{array}$ \\
\hline 15. & $\begin{array}{l}\text { Maxwell and Riley, } \\
2017\end{array}$ & & $\begin{array}{l}\text { increased emotional demands } \\
\text { hiding and acting emotions in } \\
\text { work situations }\end{array}$ & $\begin{array}{l}\text { Australia, quantitative, } \\
\text { school principals }\end{array}$ \\
\hline 16. & $\begin{array}{l}\text { Mencl, Wefald and } \\
\text { van Ittersum, } 2016\end{array}$ & good political skills & & $\begin{array}{l}\text { USA, quantitative, no } \\
\text { field specified }\end{array}$ \\
\hline 17. & $\begin{array}{l}\text { Mäkikangas, Feldt and } \\
\text { Kinnunen, } 2007\end{array}$ & $\begin{array}{l}\text { work characteristics (i.e., decision latitude, job demands, and social } \\
\text { support) affect work wellbeing linearly }\end{array}$ & & $\begin{array}{l}\text { Finland, quantitative, } \\
\text { technical field }\end{array}$ \\
\hline 18. & $\begin{array}{l}\text { Mäkikangas, } \\
\text { Hyvönen, Leskinen, } \\
\text { Kinnunen and Feldt, } \\
2011\end{array}$ & & job insecurity & $\begin{array}{l}\text { Finland, quantitative, } \\
\text { technical field }\end{array}$ \\
\hline 19. & $\begin{array}{l}\text { Nyberg, Leineweber } \\
\text { and Magnusson } \\
\text { Hanson, } 2015\end{array}$ & $\begin{array}{l}\text { managers reported benefits compared to non-managers (psychosocial } \\
\text { work factors, higher level of influence, lower level of organisational } \\
\text { injustice and better leadership), as well as the work-family interface } \\
\text { (increased enhancement between work and family domains), and } \\
\text { satisfaction and wellbeing (higher satisfaction with work and life, and } \\
\text { lower levels of short-term sickness absence) }\end{array}$ & & $\begin{array}{l}\text { Sweden, quantitative, } \\
\text { public sector, private } \\
\text { sector }\end{array}$ \\
\hline 20. & $\begin{array}{l}\text { Pagon, Spector, } \\
\text { Cooper and Lobnikar, } \\
2011\end{array}$ & job control & $\begin{array}{l}\text { poor work organisation (work } \\
\text { overload and hassles) }\end{array}$ & $\begin{array}{l}\text { Middle Europe, } \\
\text { quantitative, police }\end{array}$ \\
\hline
\end{tabular}




\begin{tabular}{|l|l|l|l|l|}
\hline & & & $\begin{array}{l}\text { bureaucratic control and reward } \\
\text { systems } \\
\text { lack of recognition } \\
\text { inappropriate organisational } \\
\text { climate }\end{array}$ & $\begin{array}{l}\text { managers, private sector } \\
\text { managers }\end{array}$ \\
\hline 21. & $\begin{array}{l}\text { Rollero, Fedi and De } \\
\text { Piccoli, 2016. }\end{array}$ & $\begin{array}{l}\text { women had higher job satisfaction } \\
\text { higher status }\end{array}$ & & $\begin{array}{l}\text { Italy, quantitative, no } \\
\text { field mentioned }\end{array}$ \\
\hline 22. & $\begin{array}{l}\text { Schmitt, Zacher and } \\
\text { Frese, 2012 }\end{array}$ & using action regulation strategy & & $\begin{array}{l}\text { Germany, quantitative, } \\
\text { university managers }\end{array}$ \\
\hline
\end{tabular}

